\title{
THE ECONOMICS THE CORRELATION ISSUES IN EU-28
}

\section{Yaser Mueeth A. Alkahtani, László Zoltán Szabó, Gan Quan}

\author{
Szent István University, Faculty of Economics and Social Sciences, Institute of Finance \\ and Business Management \\ 1-3 Doctoral School of Management and Business Administration \\ H-2100 Gödöllő, Páter Károly u. 1. \\ zsarnoczai.sandor@gtk.szie.hu
}

\begin{abstract}
In this case study the analyses focus on the some correlation compares among EU-28 member states. Also the analyses focus on the wide side overview for the EU-28 member states using eight variances of three principal components for EU-28. The economic growing rate of EU-28 member states concerning some economic issues as GDP growing rate, employment, unemployment accompanying with social protection and government debt, price fluctuating, purchase power parity of consumers and also probably lifelong learning. The eight numbers according to each variance give the average value of KMO, which shows in the first line of Table 1: KMO and Bartlett's Test, namely 0.628. In this case all of other variances expect RisPov2014 have strong correlations with themselves. The LLearn2014 has the strongest correlations by value of 0.767 (76\%), also the GovDebt2014 has strong one, by 0.744 (74\%), HICPan2014 has 0.731 (73\%), the GDPcap2014 has value of $0.706(70.6 \%)$. This SPSS statistical program can help to make clear overview for the correlations and differences among EU-28 member states from different issues and approaches, as variances. Also it is important, when the researchers choose these variances; they should know that the correlations among variances based on the principle components. These last one can select variances into different components, which mostly can explain the role and importance of each variance.
\end{abstract}

Keywords: Principle component, Different variances, KMO, Communalities, GDP growth

\section{INTRODUCTION}

This case-study overviews and analyses the correlations among the EU-28 and some economies by SPSS (Special Program for Social Sciences) in the EU-28 in main 8 different statistical fields, as components between 2005-2014, namely Total unemployment rate in \% (UnEmploy2014); GDP and main components - volumes (GDPVol2014); HICP inflation rate (HICP: Harmonised index of consumer prices, HICPan2014); General government gross debt (GovDebt2014); Expenditure on social protection (SocProt20v14); Lifelong learning in \%, Total (LLearn2014)); People at risk of poverty or social exclusion by age and sex (RiskPov2014); Real GDP per capita, growth rate and totals (GDPCap2014; the SPSS analyses can be seen SzÉLES, 2010 and SAJTOS ET AL, 2007).

In this case study the analyses focus on some correlation compares among EU-28 member states. Also the analyses focus on the wide side overview for the EU-28 member states using eight variances of three principal components for EU-28. The economic growing rate of EU-28 member states concerning some economic issues as GDP growing rate, employment, unemployment accompanying with social protection and government debt, price fluctuating, purchase power parity of consumers and also probably lifelong learning. These analyses can clear some developing trends of EU-28 member states and other international compares within EU-28. 


\section{MATERIAL AND METHOD}

The eight numbers according to each variance give the average value of KMO value, which shows in the first line of Table 1: KMO and Bartlett's Test, namely 0.628. Number of each variance shows how the given variance correlates with the other variances in percent, which should be more than 0,500 or it is given in percent, which is 0.628 (62.8 percent) in this example, therefore because this value is more than $50 \%$, the correlation among variances are strong. The Table 1: KMO and Bartlett's Test shows that the significance is very strong as 0.000 for $28 \mathrm{EU}$ member states and the significance explained by $82.330 \%$ under title of Approx. Chi-Square in the second line of the Table 1, by the other words this is the component matrix, which should be closed to about $85-90 \%$, in order that the variances can be closed to each other to determine the correlations among themselves, as these are written in table of Correlation Matrix. The correlation measure of 28 EU member states based on the 8 variances is 0.628 Tabel 1: titled as Kaiser-MeyerOkin Measure of Sampling Adequacy. Finally, it can be declared that the significance should be 0.000 , in order that the connection can be strong among the variances in case of EU-28 member states. Otherwise if the significance is far from 0.000 and closed to 0.9 and 1 value, this means that the significance is not strong.

\section{RESULTS}

The Table 2: Anti-image Matrices for Anti-image Correlation Matrix shows how the each variance from eight variants is depending on the other one and how the correlations are going on among themselves. The diagonal line starts by number $0.497^{\mathrm{a}}$ according to the UnEmploy2005-2014 to the number $0.706^{a}$ according to GDPcap2014. The Table-4-4-2: Anti-image Matrices for Anti-image Correlation Matrix the number of UnEmploy20052014 is 0.497 , which is in 49.7 percent. If this value is less than $50 \%$, this shows that this variable is weakly correlate with the other variances, if it is about $50 \%$, this can enough be correlating with other variances. If the value of variance is higher than $50 \%$ as 0.500 , this means strong correlation of one variance with others.

Table 1. KMO and Bartlett's Test

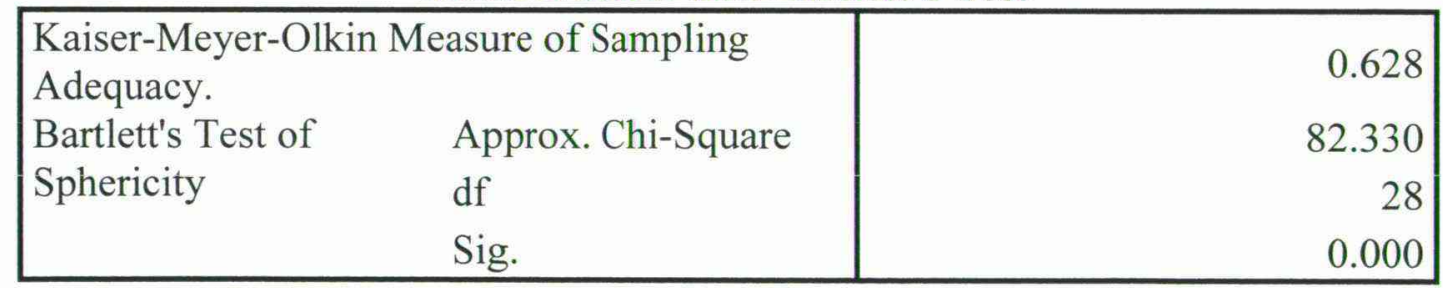

Source: Tables are owned calculated

In this case all of other variances expect RisPov2014 have strong correlations with themselves. The LLearn2014 has the strongest correlations by value of 0.767 (76\%), also the GovDebt2014 has strong one, by 0.744 (74\%), HICPan2014 has $0.731(73 \%)$, the GDPcap2014 has value of $0.706(70.6 \%)$, SocProt2014 has value of $0.646(64.6 \%)$ and the GDPVol2014 has enough strong correlation with others by value of $0.587(58 \%)$. The RisPov2014 has the most weakness correlation with to the variances by $0.261(26 \%)$. This means that if the UnEmploy2014, as unemployment decreases can be resulted by the growth of GDP volume and GDP per capita and in the same time the consuming price level (HICPan2014), the social protection (SocProt2014), life-length learning (LLearn2014) increase. Naturally the governmental debt (GovDebt2014) can increase if the 
unemployment is considerable. In this case only the RisPov2014 has weak correlations with other, namely by value of 0.261 as $26.1 \%$.

Table-2. Anti-image Matrices

\begin{tabular}{|c|c|c|c|c|c|c|c|c|}
\hline $\begin{array}{l}\text { Anti-image } \\
\text { Correlation }\end{array}$ & $\begin{array}{l}\text { UnEmploy } \\
2005-2014\end{array}$ & $\begin{array}{c}\text { GDPVol } \\
2014\end{array}$ & $\begin{array}{l}\text { HICPan } \\
2014\end{array}$ & $\begin{array}{c}\text { GovDebt } \\
2014\end{array}$ & $\begin{array}{c}\text { SocProt } \\
2014\end{array}$ & $\begin{array}{c}\text { LLeran } \\
2014\end{array}$ & $\begin{array}{c}\text { RiskPov } \\
2014\end{array}$ & $\begin{array}{c}\text { GDPcap } \\
2014\end{array}$ \\
\hline UnEmploy2014 & $.497^{\mathrm{a}}$ & .625 & .080 & -.247 & .092 & -.021 & -.439 & -.218 \\
\hline GDPVol2014 & .625 & $.587^{\mathrm{a}}$ & -.141 & -.076 & .085 & .013 & -.379 & -.234 \\
\hline HICPan2014 & .080 & -.141 & $.731^{\mathrm{a}}$ & -.042 & .539 & -.015 & -.303 & -.186 \\
\hline GovDebt2014 & -.247 & -.076 & -.042 & $.744^{a}$ & -.439 & -.025 & .158 & .090 \\
\hline SocProt2014 & .092 & .085 & .539 & -.439 & $.646^{\mathrm{a}}$ & .233 & -.439 & -.035 \\
\hline LLeran2014 & -.021 & .013 & -.015 & -.025 & .233 & $.767^{a}$ & .029 & -.419 \\
\hline RiskPov2014 & -.439 & -.379 & -.303 & .158 & -.439 & .029 & $.268^{\mathrm{a}}$ & .002 \\
\hline GDPcap2014 & -.218 & -.234 & -.186 & .090 & -.035 & -.419 & .002 & $.706^{\mathrm{a}}$ \\
\hline
\end{tabular}

a. Measures of Sampling Adequacy (MSA)

Source: Tables are owned calculated

In case of the EU-28 between 2005 and 2014 when the GDPcap2014 (Real GDP per capita, growth rate and totals) and GDPVol2014 increase based on the moderate low level of unemployment, the price level and the social protection also increase, which also provides favourable conditions for continuing the study, as LLearn2014 for the population. The GovDebt2014 can increase because the governments can decrease the taxes in order that the companies will not be pressed by taxes and they can be stimulated to increase their investments to increase the performance growth, as GDP growth finally for the EU-28. The People at risk of poverty or social exclusion by age and sex (RiskPov2014) can be fixed at the earlier same level, because this trend is going on for the longer time length for the considerable fragment of the population and therefore this one is not strongly depending on the moment prosperity economic growth rate. The strongest correlation can be seen between Unemployment rate (UnEmploy2014) and GDP Volume (GDPVol2014) between 2005 and 2014 in the EU. This is the strongest correlation means that when the GDP Volume growth rate increases within the economic prosperity with increasing investment growth in performance of the EU, the Unemployment rate decreases. Also the strong correlation can be explained by mutual connection between for example the SocProt2014, namely Expenditure on social protection (SocProt2014) and HICP - inflation rate (HICP: Harmonised index of consumer prices, HICPan2014), which means that if the expenditure on social protection is growing, this last one also stimulates the consumer prices to increase. From this point of view, the purchasing power of population increases therefore the sellers and traders increase the consuming prices. Also there the strong correlation can be proofed for example between the Expenditure on social protection (SocProt2014) and the Total unemployment rate in \% (UnEmploy2014) because naturally if the unemployment rate is growing up the social protection naturally increases. The social protection can provide more financial support to increase the study program and postgraduating courses for more and wider pert of the population of the society and increase the time-length of the studies (see Table 2).

The Communalities calculated by Table 1 and Table 2 shows the difference of each variance from the initial values, as 1,000 and show how the measure of each different 
variance is explained by the main principal components, in this case of EU-28 three components. If the difference is not too much from the 1,000 , this shows the measure of the variance is considerably explained by three principal components. If the measure of each variance is far from 1,000 , for example less than half this shows how the measure of variance is not explained strongly by three principal components. Based on this calculation the Communalities have the first variance titled as RiskPov2014 was explained by three principle components by 0.839 in case of the EU-28. GDPVol2014 is the second variance titled as (GDP and main components - volumes [nama_gdp_k], 2006-2013) which has measure explained by three principle components by 0.832 value. The third variance, namely the UnEmploy2014 has the considerable measures explained by the principle components by value of 0.829 , from owned calculated based on the data base of Eurostat. Probably the fourth variance as SocProt2014 (Expenditure on social protection in \% of GDP between 2005 and 2013) has measure explained by value of three components as 0.786 can be seen that it has strong correlations in case of EU-28 member states.

The other four variances have also considerable measure explained by three principle components in case of the EU-28 member states, namely GDPcap2014 (Real GDP per capita, growth rate and totals Percentage change on previous year, Euro per inhabitant, Percentage change on previous period between 2005 and 2014) by 0.680 ; and HICPan 2014 (HICP - inflation rate (HICP: Harmonised index of consumer prices, in Annual average rate of change \%) explained by three principles components by 0.665 ; the LLearn 2014 (Lifelong learning in \%, Total in \% of GDP) has importance and measure explained by three principle components by 0.658 ; and GovDebt 2014 has measure explained by three principle components by 0.514 . This last one has the weaker measure explained by the EU28 member states against the other variances during this period of 2005-2014. Mostly all of the variances have measure explained by the principle components over the half of the $100 \%$ measure for their importance. This analyse shows that these variances have heavy importance explained by three principle components for the economic performance of the EU-28.

Total Variance Explained show that these three main components provide $72.5 \%$ of Cumulative Initial Eigenvalues of which the first THREE components. The first component has $39.9 \%$, mostly $40.0 \%$, the second component has $17.6 \%$ and the third components has $14.943 \%$ of Cumulative from Extraction Sums of Squared Loadings. The first three components have very considerable importance to analyse performance of EU28 by closed to three-fourth of total variance explained in percent. The other components have less considerable measure in total variance explained in percent over first three components.

In Component Matrix in case of the first variance the SocPot2014 is the first variance by 0.815 ; the second variance the HICPan 2014 by 0.787 ; the third variance GovDebt 2014 by -0.681 . In the second component the first variance RisPov2014 by 0.735 ; the second variance UnEmploy 2014 by 0.605 ; the third variance GDPcap2014 by 0.539 ; in the third component the first variance GDPVol2014 by 0.649 ; the second variance RisPov 2014 by 0.536 ; third variance UnEmploy 2014 by -0.434 . Within the component matrix, each component is set up by the general average of values according to eight variances by their different values in each component. In the first component first three variances, namely the SocPot2014, the second variance the HICPan2014 and the third variance GovDebt2014 have importance. But in the second component the other first three variances have importance, as RisPov2014, UnEmploy201 and GDPcap2014. In the third component 
GDPVol2014, RisPov2014 and UnEmploy2014 variances have more importance than the other five variances. In case of the Component Matrix the first component has the first three most important variances, of which is one is GovDebt2014. Also the UnEmploy2014 variance has important role in the second and third components, because this is one of the first important variance of the second and third components. Therefore, the factor analyses are based on two figures, namely first Factor analyse is based on the UnEmploy2014 and GDPVol2014; the second Factor analyse is based on the UnEmploy2014 and GovDebt2014. The GDPVol2014 also has importance in the third component and this variance is one of the first three variances. The GDPVol2014 is the fourth variance of the first component by 0.641 and the first variance of the third component by 0.649 . Therefore the UnEmploy2014, GDPVol2014 and GovDebt2014 variances have important role either in this Factor analyses or in the real economic performance of the EU-28. In cases of Denmark and Finland also the GovDebt2014 could make influences on the increasing the GDPcap2014, income conditions even in agricultural sector and decreasing UnEmploy2014, also the favourable economic background created by agricultural and financial policies in their economies (see ZsARNÓCZAI, 2000, p 69, and 2003, p. 72). Also the strategy and theories of the bank system and its influences on the controlling system in companies can clear direction to creating favourable economic background for companies (TOON ET AL., 2014; see also in detailed in ZÉMAN ET AL., 2014).

In Component Score Coefficient Matrix in case of the first component SocProt2014 is by value of -0.255 ; HICPon 2014 by 0.247 . In case of the second component RisPov2014 by value of 0.519 ; UnEmploy2014 by 0.428 and in case of the third component GDPVol2014 has value of 0.543 , RiskPov2014 by 0.448 , UnEmploy 2014 by -0.363 and LLearn 2014 by -0.347 .

Table 3. Rotated Component Matrix ${ }^{\mathrm{a}}$

\begin{tabular}{|c|c|c|c|}
\hline \multirow{2}{*}{} & \multicolumn{3}{|c|}{ Component } \\
\cline { 2 - 4 } & 1 & 2 & 3 \\
\hline GDPVol2014 & $-\mathbf{9 0 7}$ & .083 & .078 \\
Unemploy2014 & $\mathbf{. 8 3 8}$ & .388 & .073 \\
RiskPov2014 & $\mathbf{. 5 6 1}$ & .352 & .194 \\
GovDebt2014 & .023 & $\mathbf{. 9 0 2}$ & -.029 \\
SocProt2014 & .341 & $\mathbf{. 8 0 0}$ & .032 \\
LLeran2014 & .002 & -.162 & $\mathbf{. 7 7 9}$ \\
GDPcap2014 & -.032 & .052 & $\mathbf{. 7 3 7}$ \\
\hline HICPan2014 & -.224 & -.273 &.- .449 \\
\hline
\end{tabular}

Extraction Method: Principal Component Analysis.

Rotation Method: Varimax with Kaiser Normalization.

Also there is a difficulty in case of Component matrix, that the values of the UnEmploy2014 are very high in three components, namely $-0.524,0.605$ and -0.434 , where the minus or plus values are not considerable difference, because in this case the absolute number or value is important. Also the values of GDPVol2014 are very high, namely 0.641 in first and 0.649 in the third components, the values of GDPcap2014 are very high as 0.604 in first and 0.539 in the second components. Also the RisPov2014 has high values as 0.735 and 0.536 in the first and second components. Therefore, the considerable similarly is among values in the same variances in case of different components, which makes difficulty for comparison. 
This calculation needs for creating the other calculation under the rotation system, which can be seen in the Table-3: Rotated Component Matrix. In this Table the GDPVol2014 is 0.907 in the first component while in other components the GDPVol2014 has less considerable values. Also it is the same in cases of UnEmploy2014 has value 0.838 and the RisPov2014 has value 0.561 in the first component more than one in the other components. The GovDebt2014 has 0.902 and SocProt2014 has 0.800 value in the second component more than in the others one. Also the LLearn2014 has 0,779 value and GDPcap2014 has 0.737 values in the third component more than in the other one. The rotated component structure makes possibility for comparing among variances of different components. It is very important that the values of variances should be different in the different other components (See Table 3).

\section{CONCLUSIONS}

This SPSS statistical program can help to make clear overview for the correlations and differences among EU-28 member states from different issues and approaches, as variances, like unemployment issues, GDP growth, social protection, consumer price fluctuation, lifelong learning, government debt and People at risk of poverty or social exclusion. Also it is important, when the researchers choose these variances, they should know that the correlations among variances based on the principle components. These last one can select variances into different components, which mostly can explain the role and importance of each variance.

\section{REFERENCES}

SAJTos, L., Mitev, A. (2007): SPSS kutatási és adatelemzési kézikönyv, Alinea Kiadó. $402 \mathrm{p}$.

SzÉles, I., AL-BoAinin, M.R., ZsARnócZAi, J. S. (2010):”Territorial differences or territorial similarities? - The analysís of regional competitiveness examining the 8 statistical egions of Bohemia”. pp. 139-169. In: Szücs I. et al (edited): Economics of Sustainable Agriculture. 216 p. Gödöllő: Szent István University Publishing, p. 251.

ZSARNÓCZAI, J. S. (2000): Jövedelemviszonyok és támogatási rendszer a finn mezőgazdaságban. Gazdálkodás 44(3): 67-73.

ZSARNÓCZAI, J. S. (2003): Szövetkezeti szerveződés Dániában a XXI. század elején Gazdálkodás 47(1): 71-74.

TOON, O., ZÉmAN, Z., GÁcsi, R. (2014): The theory of bank controlling. pp. 216-220. In: Controller Info Studies. Copy\&Consulting and Unio Publishing, Budapest, p. 220.

ZÉMAN, Z., SZABÓ, Z., BÁRCZI, J. (2014): Controlling aspects of risk management. [In: Zéman (edited) Controller Info Studies] Copy \& Consulting and Unio Publishing, p. 220, ISBN 978-963-08-9751-8, pp. 186-197. 